ally. On the latter date a check revealed that all three young had died, apparently one or two days previously. The young were feathered out quite well and had grown considerably since the previous visit on July 1 . The stomachs of the young were filled with caterpillars and spiders. Night temperatures during the birds' last week of life did not dip below $45^{\circ} \mathrm{F}$. and only occasional rain-showers fell during that period.

The parents were not seen again after July 7 and the reasons for the failure of the nesting remains somewhat of a mystery. From this record it appears that Starlings may also expand their breeding range into unsettled regions.

\section{UNUSUALLY LARGE BROOD SIZE OF THE SAW-WHET OWL}

\author{
by Spencer G. Sealy, Edmonton
}

On May 7, 1964, while walking through a fairly dense growth of black poplar and willow bordering a dry slough bottom five and one-half miles southeast of Battleford, Saskatchewan, I came upon what looked to me like an ordinary deserted flicker hole in a dead poplar stump some eight feet from the ground. As usual I tapped the trunk, but this time to my surprise two large eyes in the head of a Saw-whet Owl (Acgolius acadicus) appeared at the entrance - thus providing my first nesting record for this species in the Battleford area.

Desiring to investigate the situation further I proceeded to find out what was in the nest. To my surprise and amazement I pulled out nine young of various sizes. The average clutch size for this species as given by Bent in his Life Histories of North American Birds of Prey (1961:232), and by other authors, is five or six young. In a subsequent survey of the literature I was unable to find a recording of a clutch of more than seven for this species.

\section{UNUSUAL NEST SITE OF A HORNED LARK \\ by Gary Anweiler, Melville}

In the summer of $1964 \mathrm{I}$ was shown a recently vacated nest of a Horned
Lark on the back lawn of Mr. Jack Hanowski in the residential section of Melville. The nest was located in a weedy part of the lawn which is about 20 by 70 feet and which is enclosed by a six-foot board fence. The lawn was used and cut regularly over the nest, but in spite of this two young fledged at the end of July. I examined an egg which had been taken from the nest (one of the three laid) and based my identification on this as well as on the nest. This nest site is even more unusual inasmuch as there is a piece of prairie adjacent to the yard which would have provided more suitable nesting cover. Note that in the same season three young Horned Larks fledged from a nest in a newly planted lawn in Saskatoon (Blue Jay, 23:14).

\section{RECORD OF A WOOD DUCK AT ITUNA}

by Mrs. Mary F. Brennan, Ituna

In my informal account in the last Blue Jay of the pleasures of bird watching here at our farm, I mentioned a record of the Wood Duck. At the request of the editors I have gone back to my notes for the particulars of this observation. The entry for May 27, 1955, reads: "Had a real thrill today. On a walk along the north road saw two very beautiful but unfamiliar ducks. When I came home and studied the bird books, they were, without a doubt, wood ducks."

I remember the occasion well; it was a lovely spring day, and the small sloughs and willow-circled potholes along the road were still full from the spring run-off, and it was in one of these that the two ducks were swimming. I think, but at this late date, am not positive, that they were a pair, male and female.

\section{WATCH FOR YELLOW-DYED GULLS}

Early in May of this year 80 Ringbilled Gulls and two California Gulls were colored a bright yellow with a harmless dye, then banded and released near Fort Collins, Colorado. This study of gull migration is being carried out by Professor Ronald A. Ryder, Dept. of Forest Recreation and Wildlife Conservation, Fort Collins, to whom sightings of yellow gulls should be reported. 